\title{
Fabrication of Monolithic Dye-Sensitized Solar Cell Using Ionic Liquid Electrolyte
}

\author{
Seigo Ito and Kaoru Takahashi \\ Department of Electrical Engineering and Computer Sciences, Graduate School of Engineering, University of Hyogo, 2167 Shosha, \\ Himeji, Hyogo 671-2280, Japan \\ Correspondence should be addressed to Seigo Ito, itou@eng.u-hyogo.ac.jp
}

Received 15 November 2011; Accepted 6 February 2012

Academic Editor: Peter Rupnowski

Copyright (๑) 2012 S. Ito and K. Takahashi. This is an open access article distributed under the Creative Commons Attribution License, which permits unrestricted use, distribution, and reproduction in any medium, provided the original work is properly cited.

To improve the durability of dye-sensitized solar cells (DSCs), monolithic DSCs with ionic liquid electrolyte were studied. Deposited by screen printing, a carbon layer was successfully fabricated that did not crack or peel when annealing was employed beforehand. Optimized electrodes exhibited photovoltaic characteristics of $0.608 \mathrm{~V}$ open-circuit voltage, $6.90 \mathrm{~cm}^{-2} \mathrm{~mA}$ shortcircuit current, and 0.491 fill factor, yielding $2.06 \%$ power conversion efficiency. The monolithic DSC using ionic liquid electrolyte was thermally durable and operated stably for $1000 \mathrm{~h}$ at $80^{\circ} \mathrm{C}$.

\section{Introduction}

To meet the demand for renewable cost-effective energy sources, dye-sensitized solar cells (DSCs), which can be fabricated from low-cost materials $\left(\mathrm{TiO}_{2}\right.$, dye, etc.) by nonvacuum printing, have attracted attention in academic and industrial research [1-4]. DSCs are normally fabricated by sandwiching $\mathrm{TiO}_{2}$ and Pt counter electrodes. F-doped tin oxide (FTO) glass substrates for these electrodes account for $80 \%$ of DSC-fabrication cost. Additionally, Pt used in the counter electrode is also expensive. Hence, to realize further cost reductions, the use of FTO glass and Pt should be minimized. Toward this end, monolithic DSCs have been fabricated on a single FTO glass substrate with a porous carbon counter electrode (Figure 1) [5-12]. A porous carbon layer and a porous $\mathrm{ZrO}_{2}$ layer are set on dyed porous $\mathrm{TiO}_{2}$ layer for the monolithic DSC. The porous $\mathrm{ZrO}_{2}$ layer has two functions: a function as transportation of electrolyte to dyed porous $\mathrm{TiO}_{2}$ layer and a function as spacing insulator to separate dyed $\mathrm{TiO}_{2}$ layer and carbon layer electrically. There are three roles in the porous carbon layer: (1) the catalyst to reduce $\mathrm{I}_{3}^{-}$to $\mathrm{I}^{-}$for the photocurrent flow; (2) the electrical current corrector to external circuits; (3) the transportation of electrolyte to dyed-porous $\mathrm{TiO}_{2}$ and porous $\mathrm{ZrO}_{2}$. By means of capillary force within nanoholes, monolithic porous electrodes prevent electrolyte leakage. Through the use of such porous electrodes, highly durable DSCs are expected.

In research on durable DSCs, industrial applications are now being emphasized. Volatility of the DSC electrolyte has been a major problem because the interface temperature of the cell rises considerably in sunlight. To address the problem of thermal instability, the electrolyte should be nonvolatile and solvent-free, which are notable properties of ionic liquids. Accordingly, ionic liquids have been investigated for use as the electrolyte in DSCs in order to enhance their durability [13-15].

In this paper, we report a screen-printing method for fabricating porous carbon electrodes that do not crack or peel off in monolithic DSCs. In particular, we focused on carbon-paste preparation. Finally, ionic liquid electrolyte was used to prepare thermally durable monolithic DSCs that operated stably for $1000 \mathrm{~h}$ at $80^{\circ} \mathrm{C}$.

\section{Experiments}

The process for fabricating carbon paste is presented in Figure 2. Carbon powder and $\mathrm{TiO}_{2}$ powder (P25; Degussa, 


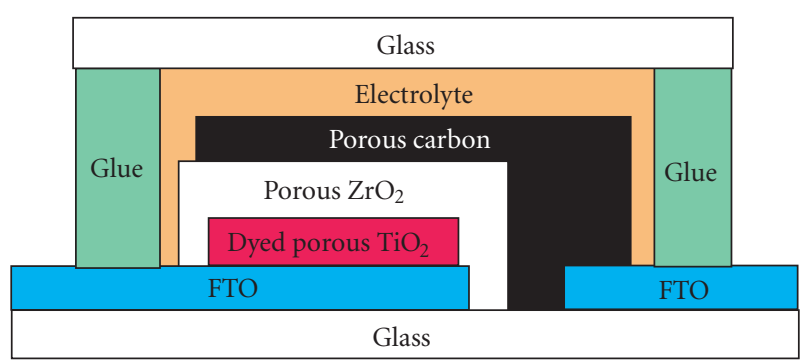

FIgURE 1: Structure of monolithic DSC.

Germany) were ground in a mortar. The carbon powder was a mixture of Printex L (Degussa) and graphite (Aldrich, Germany) or a mixture of Printex $\mathrm{L}$ and active carbon (Degussa, Germany). The total weight of carbon powder was $6 \mathrm{~g}$. Water $(10 \mathrm{~mL})$ and ethanol $(20 \mathrm{~mL})$ were added to the mortar containing the powder mixture, which was further ground. This mixture was transferred from the mortar to a beaker with an additional $100 \mathrm{~mL}$ portion of ethanol. Then, the mixture was agitated with a magnetic stir bar for $1 \mathrm{~min}$ and an ultrasonic homogenizer (Vibra Cell 72408 Bioblock Scientific, USA) for 2 min. $\alpha$-Terpineol (20 g, Tokyo Chemical Industry Co., Ltd., Japan) was added to the carbon dispersion and agitated with a magnetic stir bar for $1 \mathrm{~min}$ and an ultrasonic homogenizer for $2 \mathrm{~min}$. Ethyl cellulose solution in ethanol $(10 \mathrm{wt} \%, 30 \mathrm{~g})$ was added to the carbon solution and agitated with a magnetic stir bar for $1 \mathrm{~min}$ and an ultrasonic homogenizer for $2 \mathrm{~min}$. The ethyl cellulose solution was prepared beforehand by adding equivalent amounts of two ethyl cellulose powders in ethanol ( $5 \mathrm{wt} \%$ of ethyl cellulose no. 46080 and $5 \mathrm{wt} \%$ of ethyl cellulose no. 86480, Tokyo Chemical Industries, Co., Ltd., Japan). Removal of water and ethanol by evaporation at $40^{\circ} \mathrm{C}$ and $125 \mathrm{~m}$ bar afforded the carbon paste.

To fabricate monolithic electrodes, FTO glass plates (TEC-15, Nippon Sheet Glass Co., Ltd., Japan) were utilized. The FTO layer was divided into two parts by etching with $\mathrm{Zn}$ and $\mathrm{HCl}$ (see Figure 1). The etched FTO glass plates were washed with glass-cleaning detergent in an ultrasonic bath for $15 \mathrm{~min}$. The substrates were then rinsed with water and ethanol. Subsequently, the surface of substrate was cleaned in a UV-O ${ }_{3}$ system for $18 \mathrm{~min}$. Two types of $\mathrm{TiO}_{2}$ pastes-PST-30NRD and PST-400C (JGC-CCIC Co., Ltd., Japan)-were deposited by screen printing on one of the FTO layers (Figure 1) as a transparent nanocrystalline$\mathrm{TiO}_{2}$ layer $(10 \mu \mathrm{m}$ thick) and a light-scattering layer $(4 \mu \mathrm{m}$ thick), respectively. The resulting $\mathrm{TiO}_{2}$ electrodes had a double-layered structure [16]. The substrate was sintered on a hotplate at $500^{\circ} \mathrm{C}$ for $2 \mathrm{~h}$. When the substrate was cooled, $\mathrm{ZrO}_{2}$ paste was printed on the $\mathrm{TiO}_{2}$ layer to be $30 \mu \mathrm{m}$ thick and to cover the porous $\mathrm{TiO}_{2}$ layer. The $\mathrm{ZrO}_{2}$ paste was dried on the hotplate at $125^{\circ} \mathrm{C}$. The $\mathrm{ZrO}_{2}$ paste was prepared according to a published procedure [17] using $\mathrm{ZrO}_{2}$ nanoparticles ( $d=40-50 \mathrm{~nm}$; Fulka, USA). The substrate was heated on the hotplate at $200^{\circ} \mathrm{C}$ at $1 \mathrm{~h}$. When the substrate cooled, carbon paste was printed on the $\mathrm{ZrO}_{2}$ layer to form a

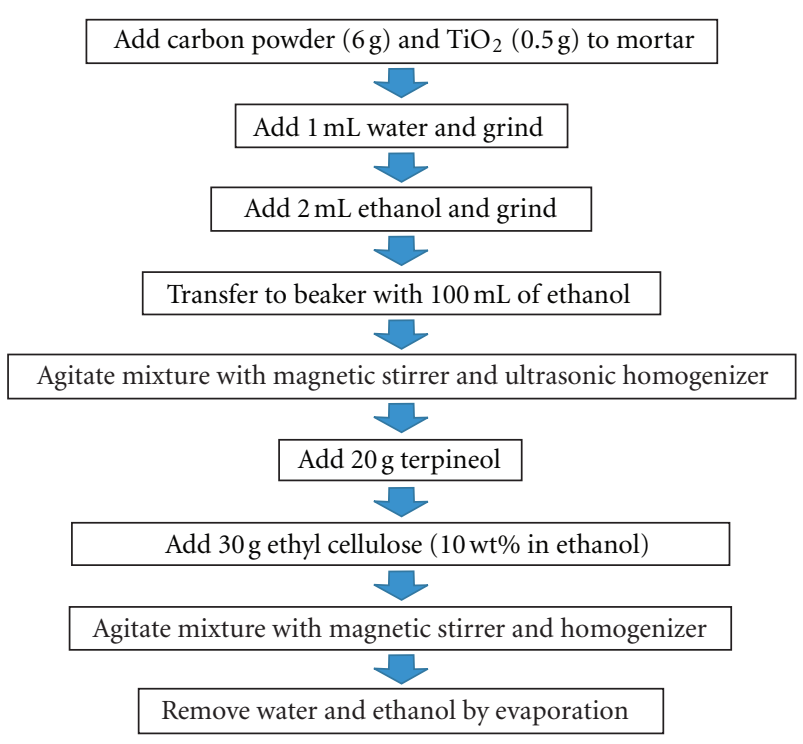

FIGURE 2: Process for preparing carbon paste for porous carbon electrode in DSCs.

layer with thickness of $130 \mu \mathrm{m}$. At the same time, the carbon layer was connected to the other FTO layer and sintered at $400^{\circ} \mathrm{C}$ (Figure 1). The fabricated electrodes were immersed in dye solution $(0.3 \mathrm{mM}$ in acetonitrile and $t$-butyl alcohol; Z907 Ru-dye, Solaronix SA) and kept at room temperature

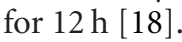

The dye-coated electrodes were rinsed with acetonitrile and combined with glass plates by heating a hot-melt glue film at $250^{\circ} \mathrm{C}$ for $1 \mathrm{~min}(150 \mu \mathrm{m}$ thick; Bynel 4164 , DuPont, USA). A drop of the electrolyte solution was placed into a hole drilled into the glass of the assembled cell and driven into the cell by vacuum backfilling. Finally, the hole was sealed using additional Bynel film and a glass cover slip $(0.1 \mathrm{~mm}$ thick). The electrolyte was composed of $0.2 \mathrm{M} \mathrm{I}_{2}, 0.5 \mathrm{M} \mathrm{N}$-methylbenzimidazole, and $0.1 \mathrm{M}$ guanidinium thiocyanate in PMII and $\operatorname{EMIB}(\mathrm{CN})_{4}$ $(13: 7 \mathrm{v} / \mathrm{v})$, which has been used in highly durability DSCs $[18,19]$.

Photovoltaic measurements employed an AM 1.5 solar simulator. The power of the simulated light was calibrated to be $100 \mathrm{~mW} \mathrm{~cm}^{-2}$ by using a reference Si photodiode equipped with an IR-cutoff filter (BS-520, BunkouKeiki Co., Ltd., Japan) to limit mismatch in the region of $350-750 \mathrm{~nm}$ between the simulated light and AM1.5 to less than $2 \%[20,21] . I-V$ curves were obtained by applying an external bias to the cell and measuring the generated photocurrent with a digital source meter (6240A, ADCMT, Japan). The thermal durability test was performed by keeping DSCs in oven at $80^{\circ} \mathrm{C}$. The sheet resistances (four-point probe method), the X-day diffraction patterns, and the electrical impedance spectra were measured using Loresta-EP MCP-T360 (Mitsubishi Chemical Analytech Co., Ltd., Japan), MiniFlex II (Rigaku Co., Ltd., Japan), and SP-150 (Bio-Logic, France), respectively. The impedance spectra were analyzed using software (Z-view 2). 


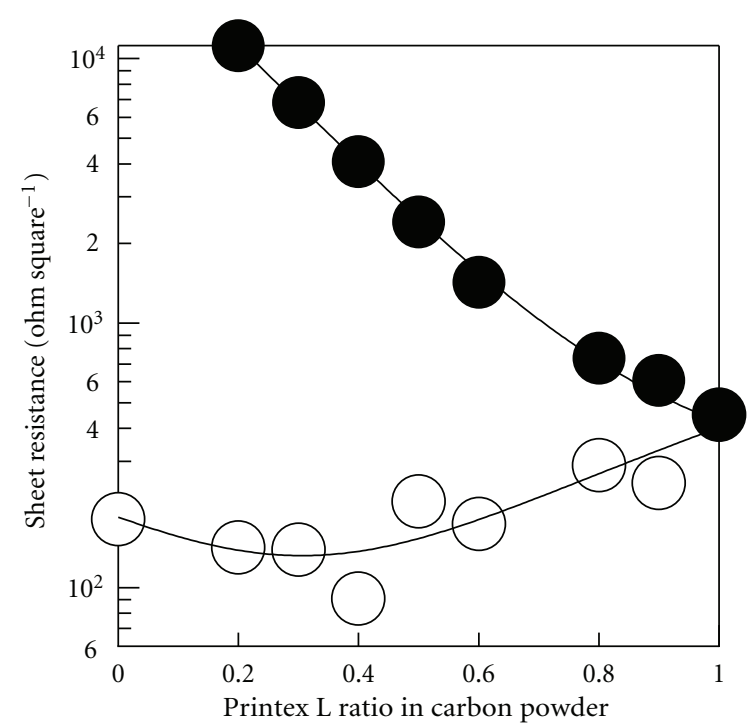

FIGURE 3: Relation between the carbon powder ratio (the ratio of Printex L in carbon powder) and sheet resistance of carbon electrode: amorphous nanocarbon (Printex L) and graphite $(\mathrm{O})$; amorphous nanocarbon (Printex L) and active carbon $(\bullet)$.

\section{Results and Discussion}

In past work, to prepare porous carbon counter electrodes for DSCs, colloidal amorphous $\mathrm{TiO}_{2}$ particles have been added as a binder for carbon particles [22]. In the present study, however, gas-synthesized $\mathrm{TiO}_{2}$ nanopowder (80\% anatase $20 \%$ rutile, P25; Degussa) was added to carbon pastes instead of colloidal amorphous $\mathrm{TiO}_{2}$. When we used colloidal amorphous $\mathrm{TiO}_{2}$ nanoparticles to fabricate thicker porous carbon layers for monolithic DSCs, the annealed carbon layer easily cracked and peeled off the substrate, likely caused by crystallization and shrinkage of the amorphous $\mathrm{TiO}_{2}$ nanoparticles. On the other hand, the gas-synthesized $\mathrm{TiO}_{2}$ nanopowder gave a thicker $(>100 \mu \mathrm{m})$, more stable porous carbon layer that did not crack or peel, because the gas-synthesized $\mathrm{TiO}_{2}$ nanopowder does not undergo further crystallization and shrinkage.

To optimize the conductivity of the porous carbon layer, the ratio of amorphous nanocarbon (Printex L) to graphite or the ratio of amorphous nanocarbon (Printex $\mathrm{L})$ to active carbon was varied. A carbon layer of 13$14 \mu \mathrm{m}$ in thickness was fabricated on the glass plate by the doctor blade method. The sheet resistance was measured by four-point probe method (Figure 3). The sheet resistance of amorphous nanocarbon (Printex L) layer was increased by adding the active carbon. In contrast, the sheet resistance of amorphous nanocarbon (Printex L) layer was decreased by adding the graphite, reaching a minimum of $90 \Omega / \square$ at $40 \%$ amorphous nanocarbon in graphite $(2.4 \mathrm{~g}$ amorphous nanocarbon (Printex L) and $3 \mathrm{~g}$ graphite). For the experiments below, carbon paste with this mixing ratio was used.

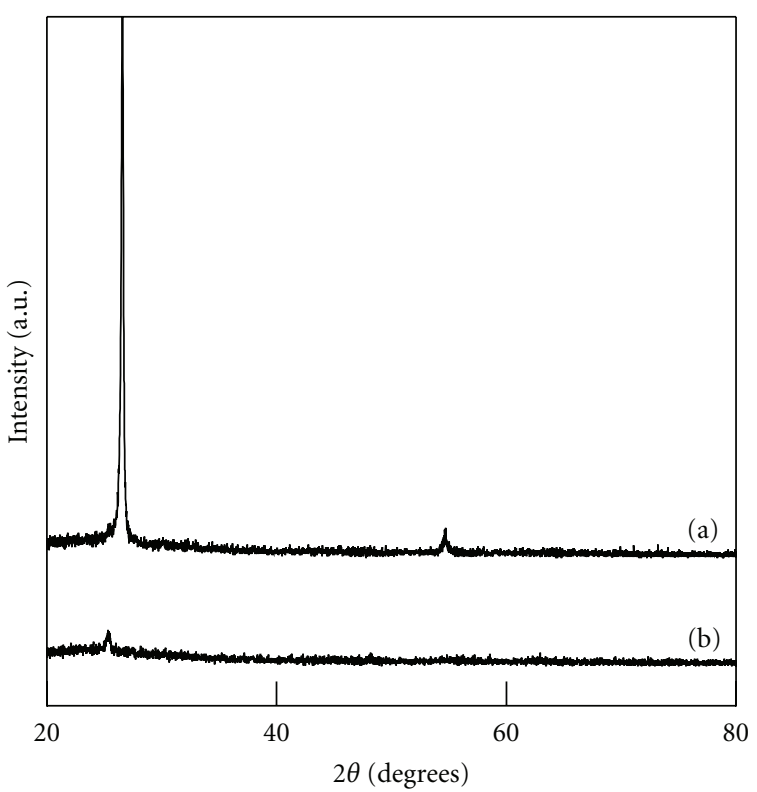

FIGURE 4: X-ray diffraction patterns of prepared carbon pastes: amorphous nanocarbon (Printex L) and graphite (a); amorphous nanocarbon (Printex L) and active carbon (b).

Figure 4 shows X-ray diffraction spectra of carbon pastes. The carbon paste containing graphite shows an intense peak attributed to the graphite structure, which is not seen in the paste using active carbon. Although the graphite can give high conductivity due to the high crystallinity, the graphite particle was so large that the connection between the graphite particles was not enough to achieve the high conductivity. On the other hand, since the amorphous nanocarbon (Printex L) was very small, the connection between the particles can be very strong. However, because of the low crystallinity of amorphous nanocarbon (Printex L), the pure amorphous nanocarbon layer was not able to improve the conductivity. Hence, the addition of amorphous carbon improved the connection between the graphite particles, resulting in the improvement of conductivity. These are the reasons why the minimum sheet resistance was obtained with $40 \%$ amorphous nanocarbon (Printex L) and 60\% graphite as shown in Figure 3.

To fabricate porous carbon layers on porous $\mathrm{TiO}_{2} / \mathrm{ZrO}_{2}$ layers, the annealing process should be optimized. Under simple heating at $400^{\circ} \mathrm{C}$ for $30 \mathrm{~min}$, the carbon layer cracked and peeled (Figure 5(a)). This cracking and peeling was found to occur on the $\mathrm{ZrO}_{2}$ layer, but not on the FTO glass plate. Therefore, peeling of the carbon layer was likely attributable to shrinkage of $\mathrm{ZrO}_{2}$. To prevent $\mathrm{ZrO}_{2}$ shrinkage from damaging the carbon layer, $\mathrm{ZrO}_{2}$ was pre-annealed at $200^{\circ} \mathrm{C}$ for $20 \mathrm{~min}$. Thereafter, carbon paste was printed on the surface of the porous $\mathrm{ZrO}_{2}$ layer, resulting in a crack-free porous carbon layer (Figure 5(b)).

Figure 6 shows the current-voltage curve of monolithic and standard sandwich-type DSCs. The Monolithic cell 


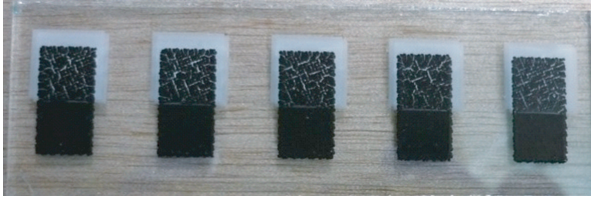

(a)

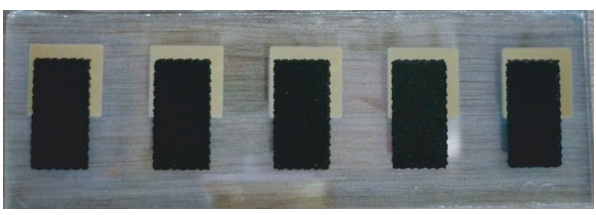

(b)

FIgURE 5: Photos of annealed carbon electrodes in monolithic DSCs: (a) without preannealing and (b) with preannealing.

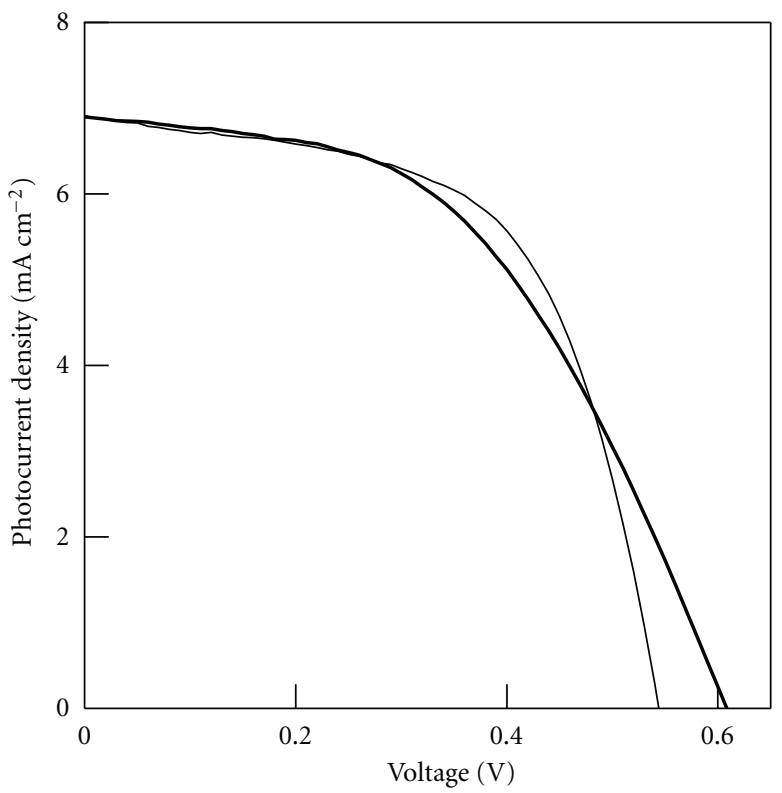

FIGURE 6: $I-V$ curves of DSCs: monolithic structure with carbon electrode (thick line); sandwich structure with Pt/FTO electrode (thin line). Dye (Z907), nanocrystalline- $\mathrm{TiO}_{2}$ electrodes, photoanode FTO, and ionic liquid electrolyte were the same in the two types of electrodes.

exhibited a short-circuit photocurrent density of $6.90 \mathrm{~mA}$ $\mathrm{cm}^{-2}$, open-circuit photovoltage of $0.608 \mathrm{~V}$, and fill factor of 0.491 , yielding a power conversion efficiency of $2.06 \%$ under AM1.5 irradiation. This photovoltaic performance was comparable to that of standard sandwich-type DSCs using Pt and FTO as counter electrodes (short-circuit photocurrent density, $6.91 \mathrm{~mA} \mathrm{~cm}^{-2}$; open-circuit photovoltage, $0.544 \mathrm{~V}$; fill factor, 0.592; power conversion efficiency, $2.22 \%$ ). The prepared monolithic DSCs performed similarly to standard sandwich-structured DSCs in terms of short-circuit photocurrent density. However, the fill factor of the monolithic

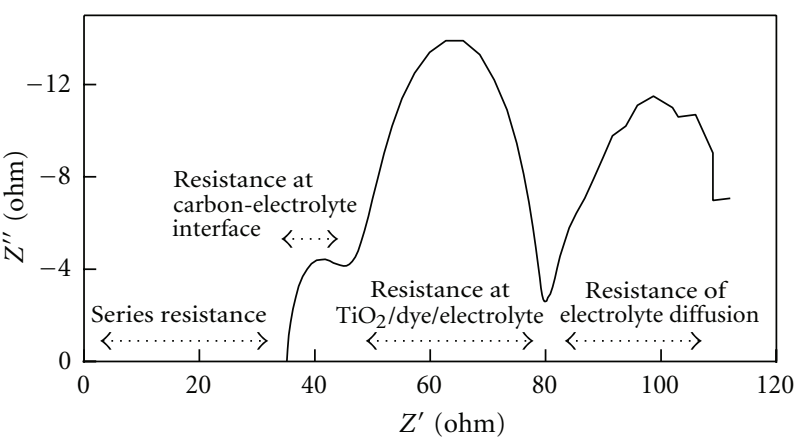

(a)

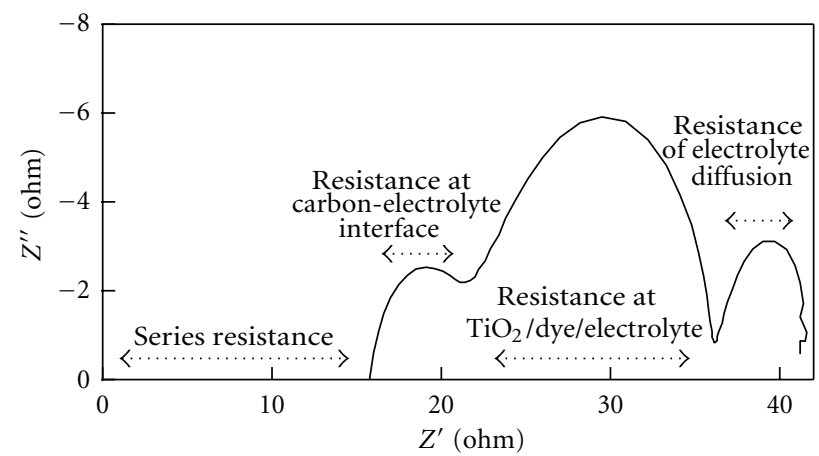

(b)

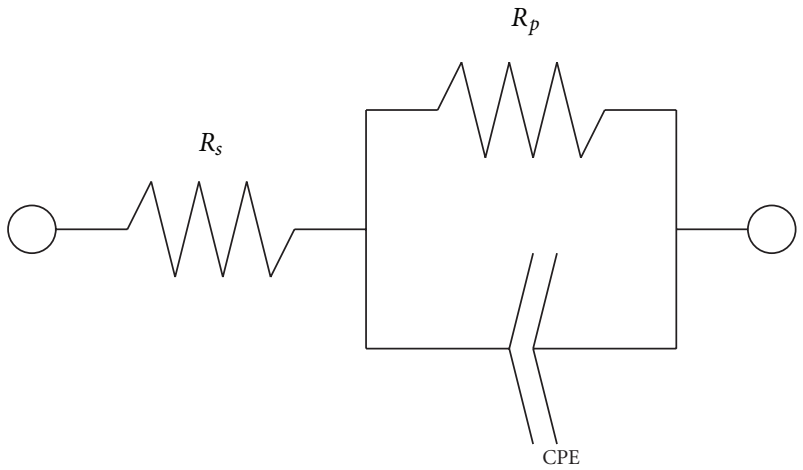

(c)

FIGURE 7: Impedance spectra (Cole-Cole plot) of monolithic- (a) and sandwich- (b) structured DSCs, which was analyzed using an equivalent circuit (c), where $R_{s}, R_{p}$, and CPE are series resistance, parallel resistance and constant-phase element (imperfect capacitance), respectively.

cells was slight lower than that of standard sandwichstructured DSCs, because the resistance of the carbon layer was higher than that of the FTO layer.

Figures $7(\mathrm{a})$ and $7(\mathrm{~b})$ show the impedance spectra of monolithic and sandwich-structured DSCs, respectively. The structure of a sandwich DSC was a standard one: < glass/FTO/porous $\mathrm{TiO}_{2} /$ dye/electrolyte/Pt/FTO/glass> [16]. The spacer between FTO-glass substrates was $35 \mu \mathrm{m}$, where the electrolyte was filled without porous- $\mathrm{ZrO}_{2}$ layer. These spectra were analyzed using an equivalent circuit (Figure 7(c)), resulting in a series resistance $\left(R_{s}\right)$, parallel resistances $\left(R_{p}\right)$, and constant-phase elements (CPE, 
TABLE 1: Impedance elements (resistance and constant-phase element) in monolithic- and sandwich-structured DSCs under photoirradiated open-circuit conditions.

\begin{tabular}{lccccccc}
\hline DSC structure & Series resistance & \multicolumn{2}{c}{ Interface of electrolyte/counter electrode } & \multicolumn{2}{c}{ Interface of $\mathrm{TiO}_{2} /$ dye/electrolyte } & \multicolumn{2}{c}{ Electrolyte diffusion } \\
\hline & $R_{s} / \Omega$ & $R_{p} / \Omega$ & $\mathrm{CPE} / \mathrm{F}$ & $R_{p} / \Omega$ & $\mathrm{CPE} / \mathrm{F}$ & $R_{p} / \Omega$ & $\mathrm{CPE} / \mathrm{F}$ \\
\hline Monolithic & 35.3 & 10.5 & $4.25 \times 10^{-6}$ & 33.8 & $2.13 \times 10^{-4}$ & 33.1 & 0.136 \\
Sandwich & 16.0 & 6.24 & $7.77 \times 10^{-6}$ & 15.2 & $3.29 \times 10^{-4}$ & 7.04 & 0.226 \\
\hline
\end{tabular}

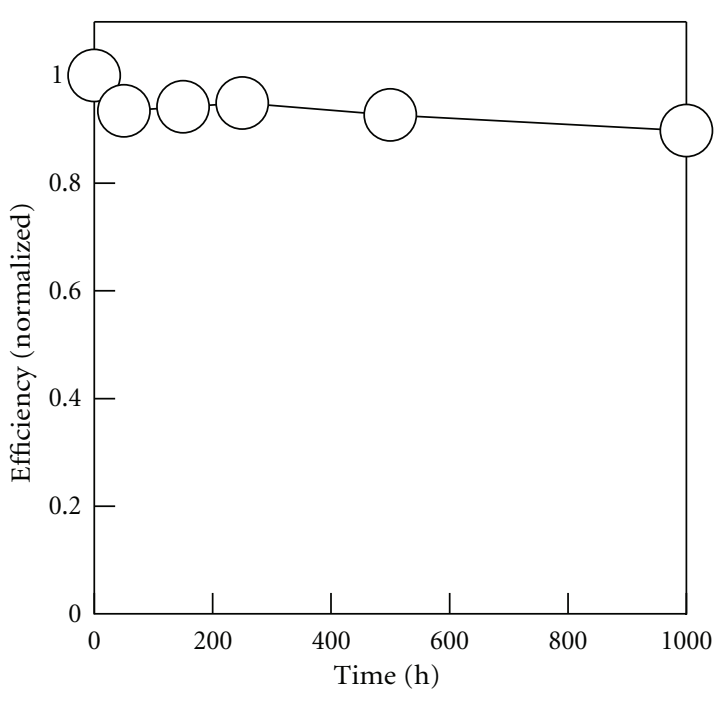

FIGURE 8: Stability test of monolithic DSC using ionic liquid electrolyte at $80^{\circ} \mathrm{C}$ in the dark.

imperfect capacitance). Each element was summarized in Table 1. The CPE is a kind of capacitance which indicates the depressed semicircles to fit the experimental spectra. In monolithic DSC, the series resistance and interface resistance between the carbon electrode and electrolyte were $35.3 \Omega$ and $10.5 \Omega$, respectively. For Pt/FTO counter electrodes, these values were $16.0 \Omega$ and $6.24 \Omega$, respectively. In addition, the diffusion resistance in the electrolyte was increased from sandwich-structured DSC $(7.04 \Omega)$ to monolithicstructured DSC (33.1 $\Omega$ ) due to the addition of the $\mathrm{ZrO}_{2}$ layer $(30 \mu \mathrm{m})$. Thus, the deterioration of fill factor was due to the incensement of resistivity by the carbon counter electrode layer and the $\mathrm{ZrO}_{2}$ layer. Further optimization is needed to improve the photovoltaic characteristic of the carbon electrode and $\mathrm{ZrO}_{2}$ layer. Figure 8 shows stability test results for an ionic liquid monolithic DSC at $80^{\circ} \mathrm{C}$ in the dark. Although the efficiency varied slightly at first, it was relatively stable in a $1000 \mathrm{~h}$ thermal test at $80^{\circ} \mathrm{C}$ [18].

In conclusion, we have reported a method using $\mathrm{TiO}_{2}$ nanopowder, instead of $\mathrm{TiO}_{2}$ colloid (P25), to prepare carbon paste that does not crack and peel. In addition, cracking due to shrinkage of the $\mathrm{ZrO}_{2}$ layer was prevented by preannealing the electrode at $200^{\circ} \mathrm{C}$ for $30 \mathrm{~min}$ before printing the carbon layer. As a result, thermally durable monolithic DSCs using ionic liquid electrolyte were prepared that operated stably at $80^{\circ} \mathrm{C}$ for $1000 \mathrm{~h}$.

\section{References}

[1] B. O’Regan and M. Grätzel, "A low-cost, high-efficiency solar cell based on dye-sensitized colloidal $\mathrm{TiO}_{2}$ films," Nature, vol. 353, no. 6346, pp. 737-740, 1991.

[2] M. Grätzel, "Photoelectrochemical cells," Nature, vol. 414, no. 6861, pp. 338-344, 2001.

[3] Y. Bai, Y. Cao, J. Zhang et al., "High-performance dyesensitized solar cells based on solvent-free electrolytes produced from eutectic melts," Nature Materials, vol. 7, no. 8, pp. 626-630, 2008.

[4] S. Ito, S. M. Zakeeruddin, P. Comte, P. Liska, D. Kuang, and M. Grätzel, "Bifacial dye-sensitized solar cells based on an ionic liquid electrolyte," Nature Photonics, vol. 2, no. 11, pp. 693698, 2008.

[5] H. Pettersson, T. Gruszecki, R. Bernhard et al., "The monolithic multicell: a tool for testing material components in dyesensitized solar cells," Progress in Photovoltaics, vol. 15, no. 2, pp. 113-121, 2007.

[6] A. Kay and M. Grätzel, "Low cost photovoltaic modules based on dye sensitized nanocrystalline titanium dioxide and carbon powder," Solar Energy Materials and Solar Cells, vol. 44, no. 1, pp. 99-117, 1996.

[7] N. Papageorgiou, P. Liska, A. Kay, and M. Grätzel, "Mediator transport in multilayer nanocrystalline photoelectrochemical cell configurations," Journal of the Electrochemical Society, vol. 146, no. 3, pp. 898-907, 1999.

[8] S. Burnside, S. Winkel, K. Brooks et al., "Deposition and characterization of screen-printed porous multi-layer thick film structures from semiconducting and conducting nanomaterials for use in photovoltaic devices," Journal of Materials Science, vol. 11, no. 4, pp. 355-362, 2000.

[9] H. Pettersson and T. Gruszecki, "Long-term stability of low-power dye-sensitised solar cells prepared by industrial methods," Solar Energy Materials and Solar Cells, vol. 70, no. 2, pp. 203-212, 2001.

[10] H. Pettersson, T. Gruszecki, L.-H. Johansson, and P. Johander, "Manufacturing method for monolithic dye-sensitised solar cells permitting long-term stable low-power modules," Solar Energy Materials and Solar Cells, vol. 77, no. 4, pp. 405-413, 2003.

[11] N. Kato, K. Higuchi, H. Tanaka, J. Nakajima, T. Sano, and T. Toyoda, "Improvement in long-term stability of dye-sensitized solar cell for outdoor use," Solar Energy Materials and Solar Cells, vol. 95, no. 1, pp. 301-305, 2011.

[12] H. Tanaka, A. Takeichi, K. Higuchi et al., "Long-term durability and degradation mechanism of dye-sensitized solar cells 
sensitized with indoline dyes," Solar Energy Materials and Solar Cells, vol. 93, no. 6-7, pp. 1143-1148, 2009.

[13] D. Kuang, P. Wang, S. Ito, S. M. Zakeeruddin, and M. Grätzel, "Stable mesoscopic dye-sensitized solar cells based on tetracyanoborate ionic liquid electrolyte," Journal of the American Chemical Society, vol. 128, no. 24, pp. 7732-7733, 2006.

[14] Y. Bai, Y. Cao, J. Zhang et al., "High-performance dyesensitized solar cells based on solvent-free electrolytes produced from eutectic melts," Nature Materials, vol. 7, no. 8, pp. 626-630, 2008.

[15] H. Matsui, K. Okada, T. Kitamura, and N. Tanabe, “Thermal stability of dye-sensitized solar cells with current collecting grid," Solar Energy Materials and Solar Cells, vol. 93, no. 6-7, pp. 1110-1115, 2009.

[16] S. Ito, T. N. Murakami, P. Comte et al., "Fabrication of thin film dye sensitized solar cells with solar to electric power conversion efficiency over 10\%," Thin Solid Films, vol. 516, no. 14, pp. 4613-4619, 2008.

[17] S. Ito, P. Chen, P. Comte et al., "Fabrication of screenprinting pastes from $\mathrm{TiO}_{2}$ powders for dye-sensitised solar cells," Progress in Photovoltaics, vol. 15, no. 7, pp. 603-612, 2007.

[18] D. Kuang, P. Wang, S. Ito, S. M. Zakeeruddin, and M. Grätzel, "Stable mesoscopic dye-sensitized solar cells based on tetracyanoborate ionic liquid electrolyte," Journal of the American Chemical Society, vol. 128, no. 24, pp. 7732-7733, 2006.

[19] D. Kuang, S. Ito, B. Wenger et al., "High molar extinction coefficient heteroleptic ruthenium complexes for thin film dye-sensitized solar cells," Journal of the American Chemical Society, vol. 128, no. 12, pp. 4146-4154, 2006.

[20] M. K. Nazeeruddin, P. Péchy, T. Renouard et al., "Engineering of efficient panchromatic sensitizers for nanocrystalline $\mathrm{TiO}_{2}$ based solar cells," Journal of the American Chemical Society, vol. 123, no. 8, pp. 1613-1624, 2001.

[21] S. Ito, H. Matsui, K. I. Okada et al., "Calibration of solar simulator for evaluation of dye-sensitized solar cells," Solar Energy Materials and Solar Cells, vol. 82, no. 3, pp. 421-429, 2004.

[22] S. Ito and Y. Mikami, "Porous carbon layers for counter electrodes in dye-sensitized solar cells: recent advances and a new screen-printing method," Pure and Applied Chemistry, vol. 83, no. 11, pp. 2089-2106, 2011. 


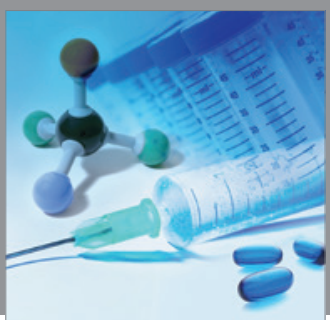

International Journal of

Medicinal Chemistry

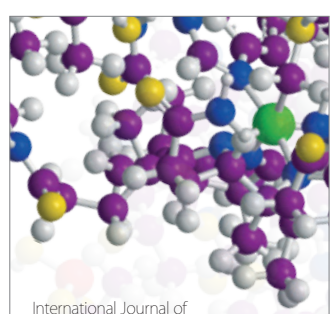

Carbohydrate Chemistry

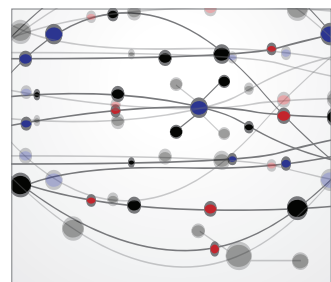

The Scientific World Journal
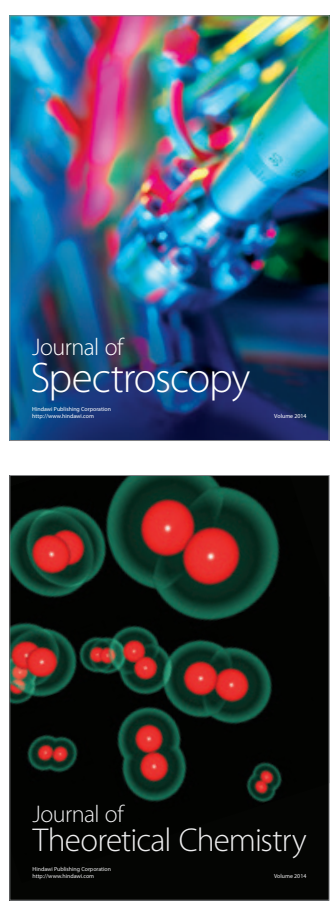
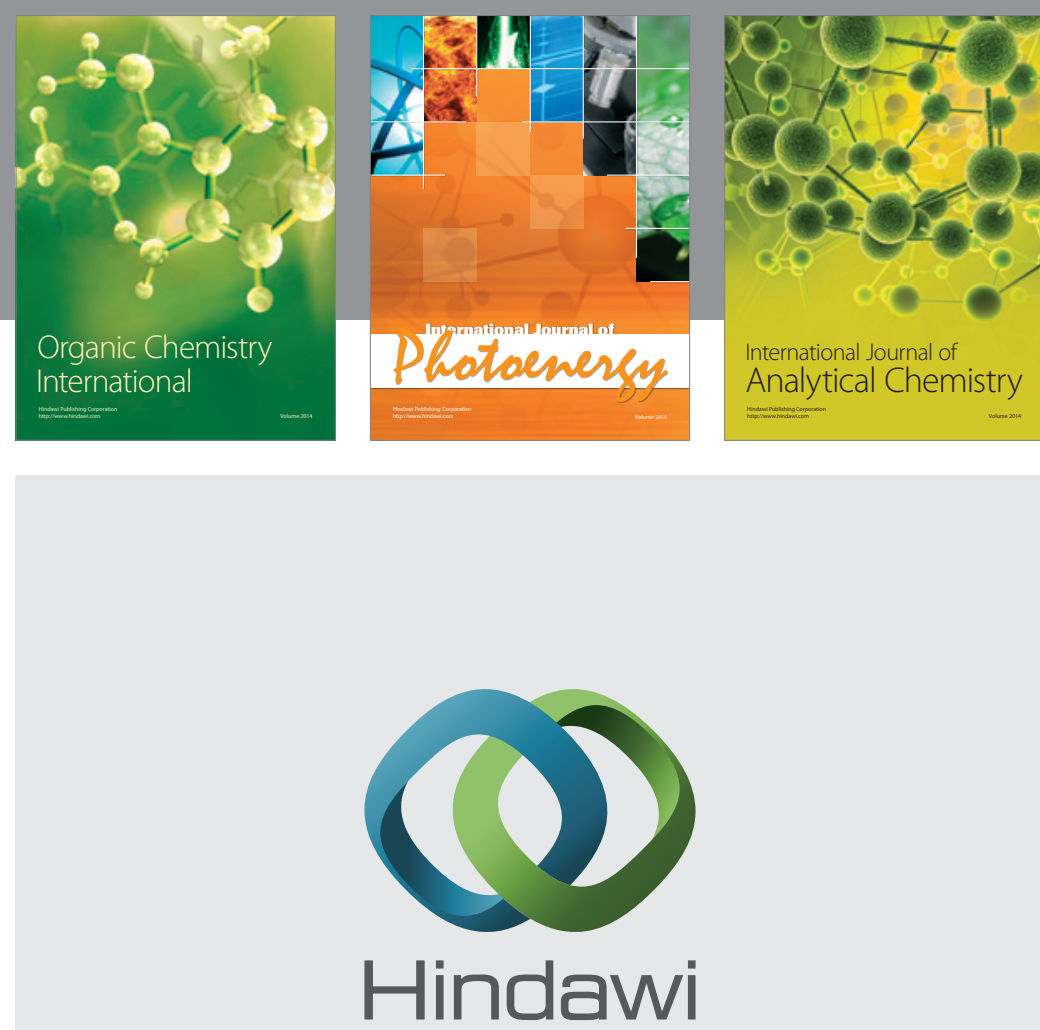

Submit your manuscripts at

http://www.hindawi.com
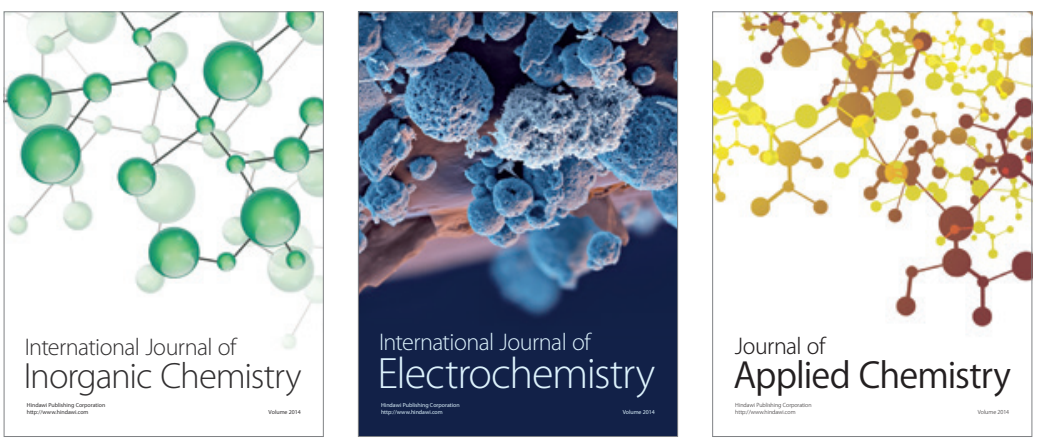

Journal of

Applied Chemistry
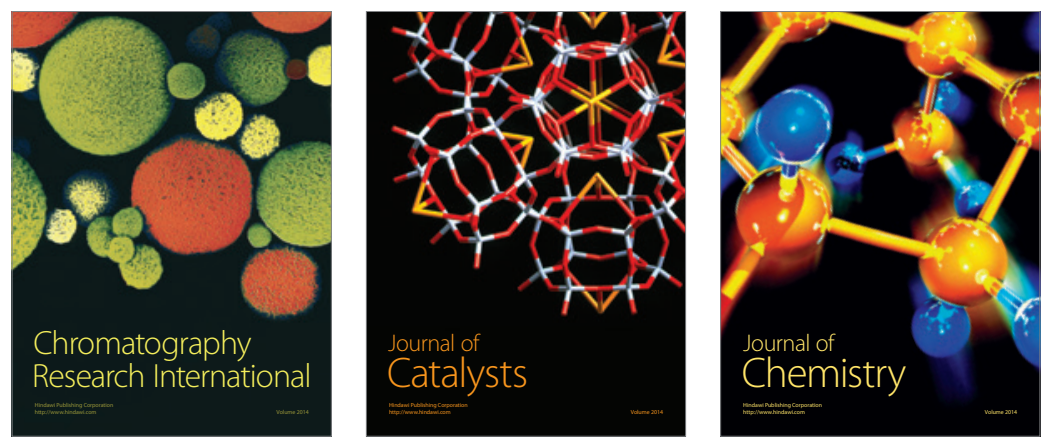
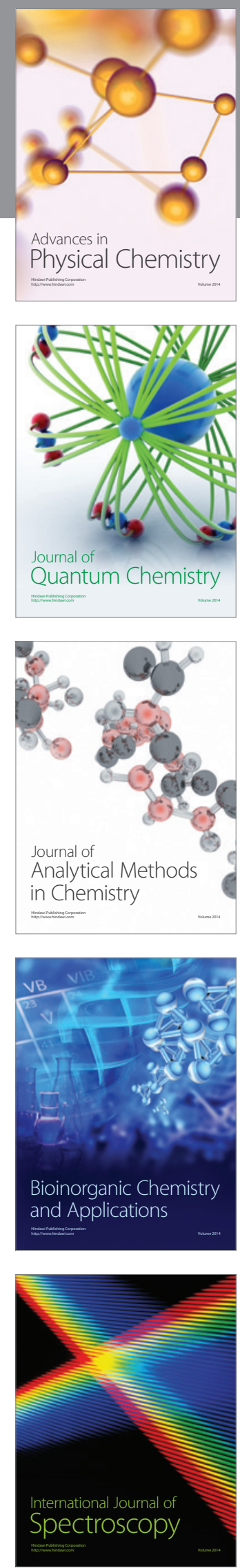